\title{
Family Ownership Structure, Independent Directors, and Independent Commissioners: Effects on Leverage
}

\author{
Yoke Yolanda ${ }^{1 *}$ and Cynthia Afriyani Utama ${ }^{2}$
}

\begin{abstract}
:
Research aims: The purpose of this research was to examine the direct relationship between family ownership structure and leverage as well as the indirect impact of independent commissioners and independent directors on the relationship between family ownership structure and leverage.

Design/Methodology/Approach: This research applied a purposive sampling technique that resulted in 22 Indonesian manufacturing public firms operating from 2010 to 2018 as the research sample. The panel data were collected from Thomson Reuters, and family ownership data were manually collected from company annual reports. This research employed multiple regression analysis with four models.
\end{abstract}

AFFILIATION:

1,2 Department of Management, Faculty of Economics and Business, Universitas Indonesia, Jakarta Capital Special Region, Indonesia

*CORRESPONDENCE:

angelayokee@gmail.com

THIS ARTICLE IS AVAILABLE IN:

http://journal.umy.ac.id/index.php/mb

DOI: 10.18196/mabis.v12i1.9525

\section{CITATION:}

Yolanda, Y. \& Utama, C.A. (2021).

Family ownership structure, independent directors, and independent commissioners: Effects on leverage. Jurnal Manajemen Bisnis, 12(1), 41-55.

\section{ARTICLE HISTORY}

Received:

08 Aug 2020

Revised:

05 Sep 2020

07 Sep 2020

Accepted:

25 Nov 2020

Research findings: The results indicated that family ownership structure was negatively significant to leverage. The independent director was not proven to strengthen the relationship between family ownership structure and leverage but rather was partially proven to do so yet the independent commissioner could not strengthen the relationship between family ownership structure and leverage.

Theoretical contribution/ Originality: This research was contributed to develop the relationship between ownership structure in family companies by involving independent commissioners and independent directors.

Practitioner/Policy implication: This research's result can help companies make financing decisions and mitigate agency problems.

Research limitation/Implication: The limitations of this research were the sample only focused on manufacturing public firms and Indonesia Stock Exchange has implemented regulations to eliminate the rule requiring each company to have an independent director, which became effective as of December 28, 2018.

Keywords: Family Ownership Structure; Independent Directors; Independent Commissioners; Leverage; Indonesia

\section{Introduction}

In some countries, especially emerging countries, business is dominated by family-owned companies (ElBannan, 2017). In Indonesia, 95\% of businesses were family-owned (Price Waterhouse Cooper, 2014). The dominance of the family company makes emerging countries vulnerable to agency problems or, in other words, conflicts exist due to differences 
Family Ownership Structure, Independent Directors, and Independent Commissioners: ...

between principal and agent interests. Based on agency theory, there are two different views regarding family ownership. First, the positive aspect of family ownership is the ability to monitor management better than non-family companies because of alignment between majority shareholders and company management, known as the alignment effect (Achleitner, Günther, Kaserer, \& Siciliano, 2014; Diyanty, 2016; Shuto \& Takada, 2010).

Second, family companies are also considered less risky for creditors than companies that are not owned by a family because managing the company requires conservative and nonrisk-seeking behaviors (Croci, Doukas, \& Gonenc, 2011). The negative side of having families as majority shareholders is that the family has the power to misuse corporate value by suppressing minority shareholders (Easterbrook, 1984; Shleifer \& Vishny, 1986), known as the entrenchment effect (Mulyani, Singh, \& Mishra, 2016). Besides, compared to minority shareholders, most shareholders who are also controlling shareholders have more accurate information related to the company's business operations.

The choice between debt and equity owned by the company is an important and crucial issue related to the company's financing decisions (Alnajjar, 2015). Capital structure is a combination of debt and equity to fund the company's operations. Therefore, the capital structure becomes crucial for all companies because the selection of the right combination of debt and equity can maximize the company's return and enable the company to compete and survive in a competitive business environment (Heng, Azrbaijani, \& San, 2012).

The existence of agency problems can be one factor in determining the capital structure companies choose. Companies that use leverage are monitored by creditors so that leverage can mitigate agency problems in the company (Agrawal \& Knoeber, 1996). Besides, leverage is also considered effective in mitigating conflicts of interest within family companies (Croci et al., 2011; Gottardo \& Moisello, 2016). The leverage that companies rely on to mitigate agency problems impacts increasing agency costs (Titman, 1984). Contradictory research results have shown empirical evidence that family companies in the United States were not overly dependent on debt to prevent adverse effects, especially loss of control over the company, and reduce financial distress and bankruptcy opportunities for the company (Mishra \& Mcconaughy, 2018). Faccio, Lang, and Young (2002) reported that family firms tend to prefer lower leverage to reduce a fixed commitment to the company's cash flow.

However, the use of leverage also creates polemics for companies in Indonesia. Indonesia lacks protection for investors and has a very high level of ownership concentration. Shareholders from the family then use the leverage so that ownership is not reduced and voting rights are maintained (Mulyani et al., 2016). In other words, the greater the ownership owned by the family, the higher the leverage (Ellul, 2011).

Indonesia also has a low level of transparency. It is evidenced by data from the Asian Development Bank (2000), suggesting that around $85 \%$ of controlling shareholders made their family members serve on the board of directors or company management. One 
Family Ownership Structure, Independent Directors, and Independent Commissioners: ...

approach that can be used to reduce agency problems in a company is an independent approach (Shleifer \& Vishny, 1986). In the context of the Indonesian state, which uses a two-tier system as a corporate governance system, this independent approach is seen by the presence of independent commissioners and independent directors in the company's board of commissioners or board of directors. Independent commissioners and independent directors who are not affiliated with shareholders and company management are expected to control the leverage used by companies whose majority shareholders are motivated to prevent takeovers and maintain voting rights.

An independent commissioner is a board that functions to supervise the implementation of corporate governance practices independently or without any party's influence to reduce conflicts and agency problems that may impact the company's value (Pratiwi \& Yulianto, 2016). In contrast, the independent director supervises the company's management. However, this independent director's presence is still not considered effective in monitoring the company's capital structure (Purag, Abdullah, \& Bujang, 2016). Thus, as of December 28, 2018, the Indonesian Stock Exchange no longer requires companies to have independent directors.

In general, research that raises the topic of family ownership structure takes the object of corporate research from the United States or Europe, and only a few articles make emerging market countries the research sample (Cheng, Lin, \& Wei, 2015; De Massis, Sharma, Chua, \& Chrisman, 2012). Having no affiliated relationship with the majority shareholders or related companies, independent commissioners and independent directors have interactions in the relationship reflected in the family ownership structure to leverage, so it is interesting to investigate how independent commissioners and independent directors interact in the relationship between family ownership structure and leverage.

Moreover, this research is limited to the manufacturing sector in public companies in Indonesia because the Family Business Survey in Indonesia by PWC (2014) stated that 29\% of gross domestic product (GDP) obtained by Indonesia came from family-owned companies; $50 \%$ was obtained from the manufacturing sector while other sectors, such as the transportation and general sectors, only provided $13 \%$, the general sector $13 \%$, the construction sector $7 \%$, and other sectors less than $5 \%$, respectively.

In its context as an emerging country, Indonesia has several critical characteristics for this research. First, $67 \%$ of companies in Indonesia were classified as family-controlled, which resulted in lower agency costs (Claessens, Djankov, Fan, \& Lang, 1999; Mulyani et al., 2016; Siagian, 2011). Second, Indonesia also implements a two-tier system in corporate governance that positions directors and commissioners in the company's organizational structure. The obstacle in Indonesia's two-tier system is that directors and commissioners in the company have a family bond with the majority shareholders. About $85 \%$ of controlling shareholders send family members to serve on the company's board of directors or commissioners (Zhuang, Edwards, \& Capulong, 2001). Thus, it is difficult for the market to conduct surveillance on the company or corporate control (Prabowo \& Simpson, 2011). 
Family Ownership Structure, Independent Directors, and Independent Commissioners: ...

Based on the above presentation, this study aims to understand (a) the negative influence of the family ownership structure on leverage for the public company in Indonesia, (b) the role of independent directors whether to strengthen or weaken the relationship of the ownership structure of family to leverage and (c) the role of independent directors to strengthen or weaken the relationship of family ownership structure to leverage.

\section{Literature Review and Hypotheses Development}

The proportion of funding applied by companies through short-term and long-term debt, or what has usually been labeled current and long-term liabilities and equity, is called capital structure. Capital structure creates corporate value, some of which comes through leverage. Leverage is an investment strategy to maximize the company's value. Leverage becomes crucial because decisions regarding the company's leverage affect the company's operational and investment financing.

This capital structure theory was introduced by Modigliani and Miller (1958). The theory was something new for the world of modern financial management. However, the theory also posed a question for researchers in that the proportion the authors propose that it is related to funding decisions on company value is considered irrelevant. From this question, other theories developed, including pecking order theory and statistical tradeoff theory.

Myers and Majluf (1984) affirmed that based on pecking order theory, companies apply a hierarchical system in making decisions regarding the capital structure used, whereas the statistical theory of trade-offs applies to the tax advantage on debt financing arising from interest expense minus taxes (Güner, 2016). It assumes that financial leverage reduces corporate income tax obligations and increases profit after tax and that the company must also pay its debt obligations.

Agency theory states that debt can be a tool to minimize agency costs (Jensen \& Meckling, 1976; Rashid, 2015). A company with controlling shareholders has a higher leverage ratio to increase voting control and reduce the possibility of a company takeover (Jandik \& Lallemand, 2017). Studies conducted by Bianco and Nicodano (2006) and supported by Mulyani et al. (2016) have proven that family-owned companies have a higher leverage ratio than non-family companies. It is because companies tend to avoid using their equity to avoid reducing ownership. Also, ElBannan (2017) undertook corporate research in Egypt and demonstrated a significant positive relationship between family ownership and leverage.

According to Jensen and Meckling (1976), the ownership structure is a pattern and form of ownership owned by companies in which the ownership structure is divided into internal block ownership and external block ownership. With the internal block ownership structure, the majority share ownership is controlled by the company management (Jensen \& Meckling, 1976). Companies classified as family-owned companies have a 
Family Ownership Structure, Independent Directors, and Independent Commissioners: ...

minimum of $10 \%$ of shares owned or controlled by the family (Hamadi, 2010; Sanjaya, 2011).

Based on pecking order theory, a company with sufficient cash or financial slack reserves prioritizes the cash or reserves as an internal fund to finance its operations and investment. The company is assisted with debt if the cash reserves are still insufficient to finance its operations and investments. The leveraged companies tend to have lower debt because they simultaneously prioritize internal funds to finance operations and investment (Gomez-Mejia, Cruz, Berrone, \& De Castro, 2016; Harris \& Raviv, 1991; Margaritis \& Psillaki, 2010). In addition to prioritizing internal company funds, concerns arise if companies depend on debt, namely, the presence of debtholders and other financial institutions that can disrupt family-owned companies (Isakov \& Weisskopf, 2015). Family firms also seek capital with a low probability of default. It means that family firms are more likely to depend on equity than leverage in their capital structure (Shleifer \& Vishny, 1986). Family-owned companies generally have a lower leverage ratio than nonfamily companies. It is because the companies are rooted in un-diversified and robust ownership that can reduce agency costs from free cash flow, which has an impact on increasing available cash in family companies. Ampenberger, Schmid, Achleitner, and Kaserer (2013), researching Germany that also applies a two-tier system in corporate governance, have proven a negative relationship between family ownership and leverage in Germany. This relationship resulted from family involvement in a public company in Germany.

Based on the concept and empirical studies described above, hypothesis 1 could be drawn as follows:

$\boldsymbol{H}_{1}$ : Family ownership has a negative influence on leverage.

The board structure in Indonesia refers to the two-tier system owned by the Netherlands. Hence, the board of companies in Indonesia consists of two components: The Board of Directors and the Board of Commissioners. It is different from other countries that adhere to a one-tier system, where only a Board of Commissioners consists of two components: The Chief Executive Officer (CEO) and the Chairman. A Board of Commissioners in a company can be appointed or dismissed by the General Meeting of Shareholders (GMS) In connection with the Indonesia Stock Exchange's new regulation on January 20, 2014, the board of commissioners and board of directors was split into independent commissioners and independent directors.

An Independent Commissioner is part of a company organization that supervises and provides direction to the company's management. Broadly speaking, the responsibility of a person who serves as an independent commissioner is to oversee company management's performance and ensure that the company implements and embodies Good Corporate Governance (GCG) principles. More specifically, the duties of the independent board of commissioners are to supervise, provide the necessary input to the company's board of directors, and ensure that the company fulfills all its responsibilities 
Family Ownership Structure, Independent Directors, and Independent Commissioners: ...

to the company's stakeholders, which of course are carried out without any interruption from any party or independently.

Before the issuance of IDX regulations on January 20,2014, independent directors were known as unaffiliated directors. Those who serve as independent directors have direct responsibility for the company's internal side to monitor company management's performance (Uyar, Kilic, \& Bayyurt, 2013).

The independent approach used in Indonesia, which applies a two-tier system, is evidenced by the independent commissioner and independent director in companies. People in those positions are expected to help top management mitigate any company agency problems (Shleifer \& Vishny, 1986). They become more objective in making decisions because minority shareholders or those who are not from the family often have little opportunity to be involved in decision-making than majority shareholders or from the family (Pranata, Purwanto, \& Lindrawati, 2019).

The presence of independent commissioners in the company serves as a mechanism to reduce agency cost by aligning shareholders' interests with company managers so that the independent commissioner variable reflects a company's ability to suppress agency cost. Besides, independent commissioners also function as supervision of independent management or are not affected by other parties in implementing governance practices within a company, impacting the value that the company will generate (Pratiwi \& Yulianto, 2016). However, it turns out that based on the research results conducted by Ampenberger et al. (2013), family involvement in company management is the reason that leverage in family firms tends to be lower than in non-family companies. Concern about irregularities in family companies' governance due to family involvement that can affect leverage as a source of financing will make the view of leverage stronger. Based on the argument above, the following hypothesis was posited:

$\boldsymbol{H}_{2}$ : Independent commissioners strengthen the negative relationship between family ownership and leverage in Indonesian manufacturing firms.

Independent directors, who are responsible as supervisors of company management who are not affiliated with the company, certainly play an essential role in overcoming agency problems, especially in family-owned companies, making decision-making better (Fama \& Jensen, 1983). However, several previous research results have found that independent directors had a negative and significant relationship with leverage. In research conducted in Iran, most independent directors were not entirely affiliated with the company (Abdoli, Lashkary, \& Dehghani, 2012). Also, in research conducted in Taiwan and Sri Lanka, company management applied a lower level of debt when corporate governance was strengthened, so that company leverage was also low (Kuo, Wang, \& Liu, 2012; Wellalage \& Locke, 2012). An Independent director who also acts as a director's supervisor who is independent in doing business at the company also gives a stronger view of leverage. Based on the argument above, the following hypothesis was proposed: 
Family Ownership Structure, Independent Directors, and Independent Commissioners: ...

$\boldsymbol{H}_{3}$ : Independent directors strengthen the negative relationship between family ownership and leverage in Indonesian manufacturing firms.

\section{Research Methods}

The data used in this research were secondary data, where the data needed in this study were a list of companies and information on sub-sectors as well as company annual reports for the period 2010-2018 from the PT. Indonesia Stock Exchange (IDX), www.idx.co.id, and Eikon Data from the Data Center of the Faculty of Economics and Business, University of Indonesia. Data on the proportion of independent directors and independent commissioners and family ownership were obtained from each company's annual reports. Other data, such as leverage (DAR and DER), company size profitability, company growth, and tax ratio, were obtained from Thomson Reuters. The sample was selected based on the purposive sampling technique, which had met the following requirements: 1 ) The company operated in the manufacturing industry listed on the Indonesia Stock Exchange; 2) The company operated during the research period 20102018 ; 3) The company published annual reports for the period 2010-2018; 4) The company did not take corporate action in 2010-2018. After the sample selection was carried out in accordance with the applicable conditions, the number of samples used in this study was 22 companies.

This study employed regression analysis with data panels. This data processing was assisted by SPSS 23 and Stata 14, where SPSS was utilized to perform descriptive analysis, normality tests, and correlation tests. Meanwhile, to choose the best model, regression tests and hypothesis testing were assisted by Stata 14 . The first thing to do in processing the regression analysis was to choose the best estimation model between common effects, fixed effects, or random effects. The best model was obtained through the Chow test and the Hausman test. The best estimation model could be continued with hypothesis testing, provided that the estimation method has passed the classical test.

The model in this study consisted of a leverage model, a proxy of a financing decision. This model was adapted from ElBannan (2017) and Mulyani et al. (2016) by using the effect of family ownership structure on leverage. However, this study's difference is on the use of fewer control variables, namely, company size and profitability. Besides, the relationship between these variables also involves the existence of an independent commissioner and an independent director as a moderating variable.

Model 1 and model 3 were used to test the direct relationship between family ownership structure and leverage (DER and DAR proxies), while models 2 and model 4 tested independent directors and independent commissioners to strengthen the relationship between family ownership structure and leverage.

Model 1

DER $i, t=\beta 0-\beta 1$ FAMOWN $i, t-\beta 2$ PROF $i, t-\beta 3$ SIZE $i, t-\beta 4$ GROW $i, t+\beta 5$ TAX $i, t+\varepsilon i, t \ldots \ldots$. Model 2 
Family Ownership Structure, Independent Directors, and Independent Commissioners: ...

DER $i, t=\beta 0-\beta 1$ FAMOWN $i, t+\beta 2$ FAMOWN*DIRIND $i, t+\beta 3$ FAMOWN*COMMIND $i, t-$ $\beta 4$ PROF $i, t-\beta 5$ SIZE $i, t-\beta 6$ GROW i,t $+\beta 7$ TAX $i, t-\varepsilon i, t . . . .$.

Model 3

DAR $i, t=\beta 0-\beta 1$ FAMOWN i,t $-\beta 2$ PROF $i, t-\beta 3$ SIZE i,t $-\beta 4$ GROW $i, t+\beta 5$ TAX $i, t+\varepsilon i, t \ldots \ldots$.

Model 4

DAR $i, t=\beta 0-\beta 1$ FAMOWN $i, t+\beta 2$ FAMOWN*DIRIND $i, t+\beta 3$ FAMOWN*COMMIND $i, t-$ $\beta 4$ PROF i,t $-\beta 5$ SIZE $i, t-\beta 6$ GROW $i, t+\beta 7$ TAX $i, t-\varepsilon i, t \ldots \ldots$.

Table 1 Summary of Variable Definitions

\begin{tabular}{|c|c|c|c|}
\hline Dependent Variable & Definition & Prior Research & Sign \\
\hline Leverage (DER) & Total debt divided by total equity & $\begin{array}{l}\text { ElBannan (2017), } \\
\text { Mulyani et al. (2016) }\end{array}$ & \\
\hline Leverage (DAR) & Total debt divided by total assets & $\begin{array}{l}\text { ElBannan (2017), } \\
\text { Mulyani et al. (2016) }\end{array}$ & \\
\hline \multicolumn{4}{|l|}{ Independent Variable } \\
\hline $\begin{array}{l}\text { Family Ownership } \\
\text { (FAMOWN) }\end{array}$ & $\begin{array}{l}\text { Total of firm equity owned by the } \\
\text { family or the affiliations in } \\
\text { percentage }\end{array}$ & $\begin{array}{l}\text { Ampenberger et } \\
\text { al. (2013) }\end{array}$ & - \\
\hline \multicolumn{4}{|l|}{ Moderation Variable } \\
\hline $\begin{array}{l}\text { Independent } \\
\text { Commissionaire } \\
\text { (COMMIND) }\end{array}$ & $\begin{array}{l}\text { Total independent commissionaire } \\
\text { divided by the total board of } \\
\text { commissionaires }\end{array}$ & $\begin{array}{l}\text { Pratiwi \& Yulianto } \\
\text { (2016) }\end{array}$ & \\
\hline $\begin{array}{l}\text { Independent director } \\
\text { (DIRIND) }\end{array}$ & $\begin{array}{l}\text { Total independent directors divided } \\
\text { by the total board of directors }\end{array}$ & Purag et al. (2016) & \\
\hline \multicolumn{4}{|l|}{ Control Variable } \\
\hline Profitability (PROF) & $\begin{array}{l}\text { Earnings before interest and taxes } \\
\text { (EBIT) divided by total assets }\end{array}$ & ElBannan (2017) & - \\
\hline Firm Size (SIZE) & $\begin{array}{l}\text { Natural logarithm of total assets at } \\
\text { the end of the financial period }\end{array}$ & ElBannan (2017) & - \\
\hline $\begin{array}{l}\text { Growth Opportunities } \\
\text { (GROW) }\end{array}$ & $\begin{array}{l}\text { Asset's market value divided by } \\
\text { asset's book value }\end{array}$ & $\begin{array}{l}\text { ElBannan (2017), } \\
\text { Jensen \& Meckling } \\
\text { (1976) }\end{array}$ & - \\
\hline Tax ratio (TAXR) & $\begin{array}{l}\text { The ratio of income taxes to pre-tax } \\
\text { income }\end{array}$ & ElBannan (2017) & + \\
\hline
\end{tabular}

\section{Results and Discussion}

In the descriptive statistical results in Table 2, the first measurement of variable leverage, DER, had an average of 0.8761 , meaning that the average ratio of debt to equity of manufacturing companies in Indonesia was 0.8761 . The DER variable also had a maximum value of 14.80 owned by PT Panasia Indo Resources Tbk (HDTX) in 2018 and a minimum value of 0.0033 owned by PT Kertas Basuki Rachmat Indonesia Tbk (KBRI) in 2012; the standard deviation owned by the DER variable was 1.53 . 
Family Ownership Structure, Independent Directors, and Independent Commissioners: ...

Table 2 Descriptive Statistics Results

\begin{tabular}{lccccc}
\hline Variable & Mean & Median & Min & Max & Std. Deviation \\
\hline DER & 0.8762 & 0.5190 & 0.0037 & 14.81 & 1.53 \\
DAR & 0.2736 & 0.2654 & 0.0033 & 0.8881 & 0.1781 \\
FamOwn & 0.3962 & 0.4460 & 0,000 & 0.980 & 0.3462 \\
Prof. & 0.0363 & 0.0346 & -0.5089 & 0.2547 & 0.0802 \\
Size & 27.78 & 27.52 & 25.33 & 30.44 & 1.1638 \\
Growth & 1.33 & 0.7303 & -6.9603 & 12.48 & 2.0710 \\
Tax Ratio & 0.2748 & 0.2607 & -5.5484 & 2.0436 & 0.6616 \\
Comm. Ind & 0.3768 & 0.3750 & 0,000 & 0.8000 & 0.1671 \\
Dir.Ind & 0.1825 & 0.1667 & 0,000 & 0.6667 & 0.1954 \\
Observation & 198 & 198 & 198 & 198 & 198 \\
\hline Source:Researche
\end{tabular}

Source: Researchers Processed Results, SPSS 23, 2019.

As for the second measurement of leverage, DAR had an average of 0.2736 , meaning that the average debt ratio to assets owned by companies in Indonesia was 0.2736 . The DAR variable also had a maximum value of 0.8881 owned by PT Tifico Fiber Indonesia Tbk (TFCO) in 2016 and a minimum value of 0.0033 owned by PT Kertas Basuki Rachmat Indonesia Tbk (KBRI) in 2012; the standard deviation owned by the DAR variable was 0.1781 .

Table 3 Summary of Empirical Testing Results

\begin{tabular}{|c|c|c|c|c|c|}
\hline \multirow[t]{2}{*}{ Variable } & \multirow[t]{2}{*}{ Sign } & \multicolumn{2}{|c|}{ Direct } & \multicolumn{2}{|c|}{ Indirect } \\
\hline & & Model 1 & Model 3 & Model 2 & Model 4 \\
\hline \multirow[t]{2}{*}{ Constanta } & & 1.9543 & $1,3551 * * *$ & 2.2616 & $1.4343 * * *$ \\
\hline & & $(0.218)$ & $(0,000)$ & $(0.185)$ & $(0,000)$ \\
\hline \multirow[t]{2}{*}{ FamOwn } & - & $-0.4863 *$ & $-0.0953 * * *$ & -0.5892 & $-0.2095 * * *$ \\
\hline & & $(0.052)$ & $(0.004)$ & $(0.159)$ & $(0.001)$ \\
\hline \multirow[t]{2}{*}{ Prof. } & - & $-3.3404 * * *$ & $-0.3735 * * *$ & $-3.2696 * * *$ & $-0.3849 * * *$ \\
\hline & & $(0.004)$ & $(0.007)$ & $(0.005)$ & $(0.005)$ \\
\hline \multirow[t]{2}{*}{ Size } & - & -0.0254 & $-0.0369 * * *$ & -0.0351 & $-0.0395 * * *$ \\
\hline & & $(0.388)$ & $(0,000)$ & $(0.347)$ & $(0,000)$ \\
\hline \multirow[t]{2}{*}{ Growth } & - & $-0.0812 *$ & -0.0071 & $-0.0894 * *$ & -0.0071 \\
\hline & & $(0.053)$ & (0.119) & (0.039) & $(0.121)$ \\
\hline \multirow[t]{2}{*}{ TaxRatio } & + & 0.1353 & 0.0171 & 0.1104 & 0.0125 \\
\hline & & $(0.182)$ & $(0.172)$ & $(0.231)$ & $(0.244)$ \\
\hline \multirow[t]{2}{*}{ FamOwn * Commlnd } & + & & & -0.6065 & 0.1675 \\
\hline & & & & $(0.326)$ & $(0.150)$ \\
\hline \multirow[t]{2}{*}{ FamOwn * Dirlnd } & + & & & 1.3468 & $0.1890 *$ \\
\hline & & & & $(0.111)$ & $(0.077)$ \\
\hline \multicolumn{2}{|l|}{ R-squared } & 0.1129 & 0.0517 & 0.1176 & 0.0810 \\
\hline \multicolumn{2}{|l|}{ Prob (F-Stat) } & 0,000 & 0,000 & 0,000 & 0,000 \\
\hline \multicolumn{2}{|l|}{ Regression Model } & FEM & REM & FEM & REM \\
\hline \multicolumn{6}{|c|}{ Level of significance: $* * *) 1 \% * *) 5 \% *$ ) $10 \%$} \\
\hline
\end{tabular}

Source: Result of statistical data using Stata 14.

The percentage of family ownership represented by the FAMOWN variable in the descriptive statistical results showed the average FAMOWN of 0.3962 (39.62\%), meaning that family members owned a $3.62 \%$ stake in Indonesia company. The FAMOWN variable 
Family Ownership Structure, Independent Directors, and Independent Commissioners: ...

had a maximum value of $98.00 \%$ owned by PT Gunawan Dianjaya Steel Tbk (GDST) in 2016 and 2017 and a minimum value of $0 \%$ owned by several companies; the standard deviation owned by the FAMOWN variable was 0.3270 .

The first moderation variable is the proportion of independent directors (DIRIND). The descriptive statistical results revealed that the average DIRIND was $0.1825(18.25 \%)$; this director's proportion value was still relatively low because BEl set regulations related to independent directors in 2014. Variable DIRIND had a maximum value of $66.67 \%$ owned by PT Panasia Indo Resources Tbk (HDTX) in 2015 and a minimum value of $0 \%$; the standard deviation owned by the DIRIND variable was 0.1954 .

Hypothesis 1 examined the effect of family ownership on leverage as measured by DER and DAR. Based on the two test results, family ownership had a significant negative relationship at the $1 \%$ confidence level. It supports hypothesis 1 , stating that the greater the amount of family ownership in a company, the lower the leverage level. In other words, $\mathrm{H} 1$ was accepted. It denoted that the company prioritized internal funds as the primary source of corporate financing in terms of investment and operations, which is also consistent with the pecking order theory. In another sense, manufacturing companies in Indonesia tend to depend on equity rather than leverage in the capital structure because manufacturing companies in Indonesia do not want to be disturbed by the presence of debtholders or financial institutions (Isakov \& Weisskopf, 2015; Shleifer \& Vishny, 1986).

The results of testing this hypothesis are similar to those of Ampenberger et al. (2013) with the research object of a company in Germany, which also applies a two-tier system. According to Ampenberger et al. (2013), the negative relationship between family ownership and leverage is caused by family involvement in company management. However, different results are reached in studies conducted in other emerging countries. For example, ElBannan (2017), performing open company research in Egypt, has proven that family ownership had a significant positive relationship with leverage.

The next hypothesis predicts the family relationship to leverage by the interaction of the presence of an independent commissioner, indicated in hypothesis 2 and the presence of an independent director, indicated in hypothesis 3.

Based on regression testing results in model 2 and model 4, the independent commissioner was positively related and not significant. In other words, the independent commissioner's role could neither strengthen nor weaken the negative relationship between family ownership and leverage.

The independent director interaction can be seen in the results of the regression tests of model 2 and model 4 . The independent director could partially strengthen the negative relationship between family ownership and leverage.

Profitability is a proxy for the availability of internal company funds that results in lower leverage. Companies with sufficient internal funds available for financing tend to have low 
Family Ownership Structure, Independent Directors, and Independent Commissioners: ...

leverage because, according to the pecking order theory, internal funding is the primary source for companies in investment financing and company operations. Therefore, in this study, profitability had a negative relationship with leverage.

The hypothesis test table for all models has proven that profitability had a negative and significant relationship to leverage. This hypothesis test results support ElBannan (2017), who studied public companies in Egypt and showed that profitability was negatively related and significant to leverage.

Company size is a proxy for access to financing. The bigger the company, the lower the leverage. In other words, company size had a negative relationship with leverage (Kurshev \& Strebulaev, 2015; Ramalho, Rita, \& da Silva, 2018; Strebulaev \& Yang, 2013).

The hypothesis test table shown from all models has confirmed that company size had a negative and significant relationship to leverage, so this study's results are consistent with previous research (Rajagopal, 2011). It showed that the larger manufacturing companies in Indonesia had greater access to the equity market and prioritized the company's internal funding sources than smaller manufacturing companies in Indonesia.

An asset's market value divided by an asset's book value becomes a measurement for the market-to-book ratio variable. Based on agency theory and cash flow theory, debt can be a tool to regulate management discipline in the company (ElBannan, 2017).

The results of regression testing uncovered that growth opportunities were partially related negatively and significantly to leverage. This study's results align with Lipson and Mortal (2009), who stated that companies that are overvalued and have a higher marketto-debt ratio tend to depend on equity as a funding source. In contrast, undervalued companies with a low market-to-debt ratio prioritize debt as a funding source. Therefore, manufacturing companies in Indonesia will rely on debt or equity, depending on their market-to-debt ratio.

The tax ratio is a proxy that reflects the effect of the company's use of the tax shield (ElBannan, 2017). However, based on the regression test results above, all models revealed that the tax ratio variable had a positive and non-significant relationship to leverage. In another sense, this study failed to find a relationship between the tax ratio and leverage.

\section{Conclusion}

Understanding the interactions arising from an independent approach to the relationship between family ownership and leverage is the study's aim. Based on the two-tier system prevailing in Indonesia, the independent approach in companies in Indonesia is evidenced by the existence of an independent commissioner and an independent director in the company. The research is limited to companies in Indonesia's manufacturing industry, with the research period spanning 2010 to 2018. 
Family Ownership Structure, Independent Directors, and Independent Commissioners: ...

This study's results indicated that family ownership influenced and was negatively related to leverage. It signified that manufacturing companies in Indonesia tended to prioritize internal funding. It implied that manufacturing companies in Indonesia did not want to rely too heavily on debt to avoid financial distress and reduce the company's chances of going bankrupt. This negative relationship is also caused by family involvement in Indonesia's company management (Ampenberger et al., 2013).

The family company's view toward decisions related to the company's capital structure has proven to be stronger. More specifically, as the party directly involved in running the company, the independent director became a moderator in the negative relationship between family ownership and leverage. However, an independent director differs from an independent commissioner who plays a role as a supervisor of the company but cannot strengthen the relationship of family ownership and leverage. Thus, what has been proven to support the company in prioritizing the use of internal funding sources was an independent director.

This research is limited to the manufacturing sector in public companies in Indonesia in the 2010-2018 research period. Besides, the Indonesia Stock Exchange has implemented regulations to eliminate the rule requiring each company to have an independent director, which became effective as of December 28, 2018.

Based on the conclusions outlined previously, this study's results imply several directions: (1) Academics who are interested in conducting research related to family ownership and leverage can expand the sector under study and use other proxies in measuring capital structure and financing decisions in family-owned companies, and (2) Companies can use this study's results as a reference in making capital structure decisions in family companies, especially with the role of independent commissioners and independent directors in the company's organizational structure.

\section{References}

Abdoli, M., Lashkary, M. \& Dehghani, M. (2012). Corporate governance and its effect on the corporatefinancial leverage. J. Basic. Appl. Sci. Res., 2(9) 8552-8560.

Achleitner, A.-K., Günther, N., Kaserer, C., \& Siciliano, G. (2014). Real earnings management and accrual-based earnings management in family firms. European Accounting Review, 23(3), 431-461. https://doi.org/10.1080/09638180.2014.895620

Agrawal, A., \& Knoeber, C. R. (1996). Firm performance and mechanisms to control agency problems between managers and shareholders. The Journal of Financial and Quantitative Analysis, 31(3), 377-397. https://doi.org/10.2307/2331397

Alnajjar, M. I. M. (2015). Business Risk impact on capital structure : A case of jordan industrial sector. Global Journal of Management and Business Research 15(1): 1-7. Retrieved from https://globaljournals.org/item/4500-business-risk-impact-on-capital-structurea-case-of-jordan-industrial-sector

Ampenberger, M., Schmid, T., Achleitner, A.-K., \& Kaserer, C. (2011). Capital structure decisions in family firms: empirical evidence from a bank-based economy. Review of Managerial Science, 7(3), 247-275. https://doi.org/10.1007/s11846-011-0077-2

Bianco, M., \& Nicodano, G. (2006). Pyramidal groups and debt. European Economic Review, 
Family Ownership Structure, Independent Directors, and Independent Commissioners: ...

50(4), 937-961. https://doi.org/10.1016/i.euroecorev.2004.11.001

Cheng, M., Lin, B., \& Wei, M. (2015). Executive compensation in family firms: The effect of multiple family members. Journal of Corporate Finance, 32, 238-257.

https://doi.org/10.1016/j.jcorpfin.2014.10.014

Claessens, S., Djankov, S., Fan, J., \& Lang, L. (1999). Expropriation of Minority Shareholders in East Asia. Washington, DC: World Bank.

Croci, E., Doukas, J. A., \& Gonenc, H. (2011). Family control and financing decisions. European Financial Management, 17(5), 860-897. https://doi.org/10.1111/j.1468036X.2011.00631.X

De Massis, A., Sharma, P., Chua, J. H., \& Chrisman, J. J. (2012). Family business studies: An annotated bibliography. Family Business Studies: An Annotated Bibliography. https://doi.org/10.4337/9781781002988

Diyanty, V. (2016). Does the pyramidal ownership mechanism negatively affect the firm's performance? Journal of Economics, Business \& Accountancy Ventura, 19(2), 205. https://doi.org/10.14414/jebav.v19i2.467

Easterbrook, F. H. (1984). American economic association two agency-cost explanations of dividends author. American Economic Association Stable.

ElBannan, M. A. (2017). Stock market liquidity, family ownership, and capital structure choices in an emerging country. Emerging Markets Review, 33, 201-231. https://doi.org/10.1016/i.ememar.2017.11.001

Ellul, A. (2011). Control motivations and capital structure decisions. SSRN Electronic Journal. March, 1-48. https://doi.org/10.2139/ssrn.1364661

Fama, E. F., \& Jensen, M. C. (1983). Agency problems and residual claims. The Journal of Law and Economics, 26(2), 327-349. https://doi.org/10.1086/467038

Gomez-Mejia, L. R., Cruz, C., Berrone, P., \& De Castro, J. (2011). The bind that ties: Socioemotional wealth preservation in family firms. The Academy of Management Annals, 5(1), 653-707. https://doi.org/10.1080/19416520.2011.593320

Gottardo, P., \& Moisello, A. M. (2016). The Impact of Family Control and Influence on Leverage. European Journal of Economics, Finance and Administrative Sciences, 87, 5-24. Retrieved from https://www.europeanjournalofeconomicsfinanceandadministrativesciences.com/issue s/EJEFAS 87.html

Güner, A. (2016). The Determinants of capital structure decisions: New evidence from Turkish companies. Procedia Economics and Finance, 38, 84-89. https://doi.org/10.1016/s2212-5671(16)30180-0

Hamadi, M. (2010). Ownership concentration, family control and performance of firms. European Management Review, 7(2), 116-131. https://doi.org/10.1057/emr.2010.9

Harris, M., \& Raviv, A. (1991). The theory of capital structure. The Journal of Finance, 46(1), 297-355. https://doi.org/10.1111/j.1540-6261.1991.tb03753.x

Heng, T. B., Azrbaijani, S., \& San, O. T. (2012). Board of directors and capital structure: Evidence from leading Malaysian companies. Asian Social Science, 8(3). https://doi.org/10.5539/ass.v8n3p123

Isakov, D., \& Weisskopf, J.-P. (2015). Pay-out policies in founding family firms. Journal of Corporate Finance, 33, 330-344. https://doi.org/10.1016/i.jcorpfin.2015.01.003

Jandik, T., \& Lallemand, J. (2017). Do capital structure adjustments by takeover targets influence acquisition gains? Financial Review, 52(2), 171-198. https://doi.org/10.1111/fire.12134

Jensen, M. C., \& Meckling, W. H. (1976). Theory of the firm: Managerial behavior, agency costs and ownership structure. Journal of Financial Economics, 3(4), 305-360.

https://doi.org/10.1016/0304-405X(76)90026-X 
Family Ownership Structure, Independent Directors, and Independent Commissioners: ...

Kuo, H., Wang, L. \& Liu, H. (2012). Corporate governance and capital structure : Evidence from Taiwan SMEs. Review of Economics \& Finance, 43-58.

Kurshev, A., \& Strebulaev, I. A. (2015). Firm size and capital structure. Quarterly Journal of Finance, 5(3). https://doi.org/10.1142/S2010139215500081

Lipson, M. L., \& Mortal, S. (2009). Liquidity and capital structure. SSRN Electronic Journal. https://dx.doi.org/10.2139/ssrn.887413

Margaritis, D., \& Psillaki, M. (2010). Capital structure, equity ownership and firm performance. Journal of Banking \& Finance, 34(3), 621-632. https://doi.org/10.1016/j.jbankfin.2009.08.023

Mishra, C. S., \& Mcconaughy, D. L. (1999). Founding family control and capital structure: The risk of loss of control and the aversion to debt. Entrepreneurship Theory and Practice, 23(4), 53-64. https://doi.org/10.1177/104225879902300404

Modigliani, F., \& Miller, M. (1958). The cost of capital, corporation finance and the theory of investment. The American Economic Review, 48(3), 261-297. Retrieved from http://www.jstor.org/stable/1809766

Mulyani, E., Singh, H., \& Mishra, S. (2016). Dividends, leverage, and family ownership in the emerging Indonesian market. Journal of International Financial Markets, Institutions and Money, 43, 16-29. https://doi.org/10.1016/j.intfin.2016.03.004

Myers, S. C., \& Majluf, N. S. (1984). Corporate financing and investment decisions when firms have information that investors do not have. Journal of Financial Economics, 13(2), 187-221. https://doi.org/10.1016/0304-405x(84)90023-0

Prabowo, M., \& Simpson, J. (2011). Independent directors and firm performance in family controlled firms: Evidence from Indonesia. Asian-Pacific Economic Literature, 25(1), 121132. https://doi.org/10.1111/j.1467-8411.2011.01276.x

Pranata, J., Purwanto, M., \& Lindrawati. (2019). Pengaruh family ownership dan direktur independen terhadap kinerja perusahaan. Seminar Nasional Ilmu Terapan (SNITER) Universitas Widya Kartika, 53, 1689-1699.

Pratiwi, R., \& Yulianto, A. (2016). Pengaruh struktur kepemilikan dan komisaris independen terhadap biaya keagenan perusahaan yang masuk dalam indonesia most trusted companies. Management Analysis Journal, 5(3), 215-228. Retrieved from https://journal.unnes.ac.id/sju/index.php/maj/article/view/11119

Price Waterhouse Cooper. (2014). Survey bisnis keluarga 2014. Retrieved from https://www.pwc.com/id/en/publications/assets/indonesia-report-family-businesssurvey-2014.pdf

Purag, M.B., Abdullah, A.B. \& Bujang, I. (2016). CG \& CS Malaysia family owned companies. Joumal of Business and Retail Management Research (JBRMR), 11(1), 18-30. Retrieved from https://ibrmr.com/details\&cid $=240$

Rajagopal, S. (2011). The portability of capital structure theory: Do traditional models fit in an emerging economy? Journal of Finance and Accountancy, 5, 1-17. Retrieved from http://scholar.google.com/scholar_lookup?hl=en\&volume=5\&publication_year=201 1\&pages $=1$ -

$17 \&$ author $=$ S. + Rajagopal\&title $=$ The + portability + of + capital + structure + theory $\% 3 \mathrm{~A}+$ Do + traditional + models + fit + in + an + emerging + economy $\% 3 \mathrm{~F}$

Ramalho, J. J., Rita, R. M., \& da Silva, J. V. (2018). The impact of family ownership on capital structure of firms: Exploring the role of zero-leverage, size, location and the global financial crisis. International Small Business Journal: Researching Entrepreneurship, 36(5), 574-604. https://doi.org/10.1177/0266242617753050

Rashid, A. (2014). Revisiting agency theory: Evidence of board independence and agency cost from Bangladesh. Journal of Business Ethics, 130(1), 181-198. https://doi.org/10.1007/s10551-014-2211-y 
Family Ownership Structure, Independent Directors, and Independent Commissioners: ...

Sanjaya, I. P. S. (2011). The influence of ultimate ownership on earnings management: Evidence from Indonesia. Global Journal of Business Research. 5(5), 61-69. Retrieved from https://core.ac.uk/download/pdf/35391817.pdf\#page=579

Shleifer, A., \& Vishny, R. W. (1986). Large shareholders and corporate control. Journal of Political Economy, 94(3, Part 1), 461-488. https://doi.org/10.1086/261385

Shuto, A., \& Takada, T. (2010). Managerial ownership and accounting conservatism in Japan: A test of management entrenchment effect. Journal of Business Finance \& Accounting, 37(7-8), 815-840. https://doi.org/10.1111/j.1468-5957.2010.02196.x

Siagian, F. T. (2011). Ownership structure and governance implementation : Evidence from Indonesia. International Journal of Business, Humanities and Technology. 1(3). https://www.ijbhtnet.com/journal/index/79

Strebulaev, I. A., \& Yang, B. (2013). The mystery of zero-leverage firms. Journal of Financial Economics, 109(1), 1-23. https://doi.org/10.1016/i.jfineco.2013.02.001

Titman, S. (1984). The effect of capital structure on a firm's liquidation decision. Journal of Financial Economics, 13(1), 137-151. https://doi.org/10.1016/0304-405X(84)90035-7

Uyar, A., Kilic, M., \& Bayyurt, N. (2013). Association between firm characteristics and corporate voluntary disclosure: Evidence from Turkish listed companies. Intangible Capital, 9(4). https://doi.org/10.3926/ic.439

Wellalage, N. H., \& Locke, S. (2014). The capital structure of sri lankan companies: A quantile regression analysis. Journal of Asia-Pacific Business, 15(3), 211-230. https://doi.org/10.1080/10599231.2014.934627

Zhuang, J., Edwards, D., \& Capulong, M. V. A. (2001). Corporate Governance and Finance in East Asia: A Study of Indonesia, Republic of Korea, Malaysia, Philippines and Thailand. Asian Development Bank. Retrieved from https://thinkasia.org/handle/11540/6222 